\title{
India's Look/Act East Policy and the Northeast Region: A Critical Perspective
}

Hiranya K. Nath ${ }^{+*}$ and Siddharth Kumar ${ }^{\breve{ }}$

\section{Abstract}

India's Look East Policy (LEP) signifies a strategic shift in its international political, economic, and military relationships. Regional integration of its Northeast Region (NER) with the countries in East, Southeast and South Asia may potentially generate economic dividends to the region. However, there are formidable challenges in realizing the potentials. The proposed infrastructure projects, if completed with no further delay, will go a long way in improving connectivity with the neighbouring countries. However, improving connectivity within the region and with the rest of the country is also very important. Further, it would require a comprehensive long-term plan with well-defined projects for developing industries and services including education, health and tourism. Building infrastructure, ensuring socio-political stability and ecological balance, and improving the quality of institutions would be a major part of this plan.

Keywords: Look East Policy (LEP), Act East Policy (AEP), India's Northeast Region (NER)

\footnotetext{
${ }^{\dagger}$ Professor, Department of Economics and International Business, Sam Houston State University, Huntsville, Texas 77320 (USA), Email:eco_hkn@shsu.edu

Corresponding Author

IMA Student, Department of Humanities and Social Sciences, Indian Institute of Technol ogy Guwahati, Guwahati, Assam 781039 (India), Email: siddharthkumariitg@gmail.com

(C) 2017 Nath and Kumar. This is an Open Access article distributed under the terms of the Creative Commons Attribution License (http://creativecommons.org/licenses/by/2.0), which permits unrestricted use, distribution, and reproduction in any medium, provided the original work is properly cited.
} 


\section{Introduction}

This paper presents a critical assessment of some of the potential gains from and challenges of India's erstwhile Look East Policy (LEP) and more recent Act East Policy (AEP) for its northeast region (NER). There has been much euphoria about the benefits that are likely to accrue to NER from the successful implementation of LEP/AEP. The opening of the eastern and southern borders of the region to the countries in East, South and Southeast Asia is expected to establish direct and easy connectivity that is purported to contribute not only to its economic growth and development but also to cultural exchanges. Improved connectivity with the Southeast Asian countries is expected to create and boost trade and investment. Even the distance between NER and the rest of India is likely to be reduced, and this will go a long way in improving economic ties and boosting cultural exchanges. For historical reasons, despite its physical proximity, NER has been kept isolated from the countries in South and Southeast Asia region and is connected to the mainland India through a narrow corridor of about 21 kilometre, often referred to as the 'chicken's neck'. ${ }^{1}$

As the large transfer of resources under various central government schemes and policies since the early 1990s failed to pay the long-term economic dividends, the development policy for the region needed a new paradigm. In that respect the LEP and later AEP have provided with this new framework for the region's growth and development. In this framework, regional integration with the neighbouring countries of East and Southeast Asia can be thought of as the canvas that will facilitate formulation and implementation of appropriate policies. Geographic proximity, historic relationships and ethno-cultural affinity are purported to be the underlying principles for such regional integration.

While increased connectivity under LEP/AEP is expected to increase trade flows to the region

\footnotetext{
${ }^{1}$ This narrow corridor has been referred to as 'chicken's neck' in many books and articles. For example, see Bhaumik (2014).
}

and thus to contribute to its economic growth, it is not quite clear what the region will trade with the countries in the East and Southeast Asian region. Further, unless and until the intraregional connectivity is improved - which is a task of tall order - it will be impossible for the region to reap the benefits. ${ }^{2}$ Furthermore, in order to attract investment from outside the region, removing the infrastructural bottlenecks alone will not be enough. There is a need for a comprehensive policy to ensure socio-political stability and for improving efficiency and quality of the institutions.

The rest of the paper is organised as follows. In the next section, we present a brief economic profile of NER. Following this, it briefly discusses India's LEP/AEP. The opportunities created by LEP/AEP for the region and the challenges in realising those opportunities are critically discussed in the penultimate section. The final section includes our concluding remarks.

\section{The NER: A Brief Profile and Background}

Although the NER originally comprised seven contiguous states (also known as seven sisters) of the northeast region of India, it now officially includes the Himalayan state of Sikkim as well. ${ }^{3}$ There are several important features of the region. The region is landlocked and connected to the mainland of India through a narrow strip of land. It shares 98 percent of its boundary with foreign countries: Bangladesh, Bhutan, China, Myanmar and Nepal. Because of this long international border, this region has been considered strategic and sensitive from the point of view of national defense. The IndoChina war of 1962 and the China's continual claim over Arunachal Pradesh have made it even more sensitive. Further, the alleged links

\footnotetext{
${ }^{2}$ For a discussion, see Barua and Das (2008)

${ }^{3}$ Sikkim was added as the eighth member of the North Eastern Council (NEC) by the North Eastern Council (Amendment) Act of 2002 and has been considered a part of NER since then. A copy of the act can be downloaded from the NEC Website at: http://necouncil.gov.in/writereaddata/mainlinkfile/THE\% 20NORTH\%20EASTERN\%20COUNCIL\%20AMENDMENT\% 20ACT\%202002.pdf (accessed on Friday, September 1, 2017)
} 
of various insurgent groups operating in the northeast region with groups in Myanmar and Bangladesh contribute to the international sensitivity. Due to these considerations, the borders have been closed and it has exacerbated the problems associated with the landlocked nature of the region.

There are about 220 dialects in multiple language families (Indo-European, Sino-Tibetan, Austroasiatic) that share common structural features. ${ }^{4}$ Further, with more than two hundred ethnic groups, the region is heavily fractionalised. The hills states in the region like Arunachal Pradesh, Meghalaya, Mizoram, and Nagaland are predominantly inhabited by tribal people. However, there is a great deal of diversity within the tribal groups. There have been continuous flows of migration from Tibet, Indo-Gangetic India, the Himalayas, present Bangladesh and Myanmar for a long period. With only 25 seats in the Lok Sabha and 14 seats in the Rajya Sabha, NER is also in the periphery of Indian polity.

\section{The Macro Reality of 8-4-3}

The share of the region in India's landmass, population, and income - which we summarise in 8-4-3 - reflects its big picture reality. With 262 thousand square kilometre, NER accounts for $8 \%$ of the total area of the country. Among the northeastern states, Arunachal Pradesh is the largest in geographical area followed by Assam, and Sikkim is the smallest. According to the 2011 census, about 46 million people live in the region. Thus, these eight states together account for about $4 \%$ of the total population of India. Figure 1(a) and 1(b) show the percentage distribution of area and population by different northeastern states. These two facts imply that the population density in the region is relatively lower than the rest of the country.

The average share of domestic products generated in the region has been about 3\% of which Assam alone contributes two-thirds (see Figure 1[c]). In terms of the sectoral composition, the share of the agricultural

\footnotetext{
${ }^{4}$ For a detailed discussion on languages of NER, see Moral (1997).
}

sector is larger for the region than for the national economy. The share for the region was about $23 \%$ whereas it was $18 \%$ for the country in 2013-14. The respective shares of industry and service are smaller for the region than for the nation. However, as Figure 1(d) depicts, there are variations across states. For example, agriculture is the largest segment of the economy of Arunachal Pradesh whereas industry is the largest in Sikkim. In contrast, the service sector share in Manipur, Mizoram, Nagaland, and Tripura is larger than the national average.

Despite various government incentives, the growth of the industry sector has been lackadaisical. At the time of independence, the region, particularly Assam, inherited a modern industrial sector that consisted of plantation and manufacturing of tea, mining of coal and oil, refining of oil, manufacturing of plywood, and other forest resources-based products. The British colonial power also left behind a reasonably well developed railway network for transportation of the industrial products. However, due to the partition of the country at independence, the approach routes to the region were cut off and it had to be connected through a narrow corridor in the North Bengal. This became a big hurdle for economic integration with the rest of the country. Further, as Bezbaruah and Sarma (2009) point out, political considerations played an important role in deciding the location of massive public sector enterprises during the post-independence period.

Over the past 35 years, the total share of the region in India's domestic product has been around 3 percent. However, as Figure 2 shows, the share has declined over time indicating that the region has been growing at a slower rate than the rest of the country. It has missed several trains of economic growth. Unlike in Punjab and other parts of India, the Green Revolution of the late 1960s-1970s did not have any significant impact on agriculture in the region. The region also missed the industrial revolution of the late 1980s and the 1990s. 
Percentage Share in Total (India) Area

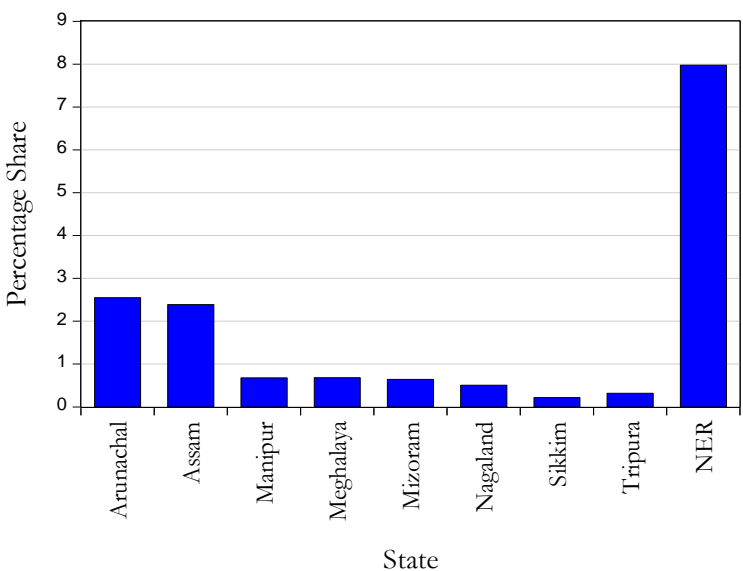

(a)

Percentage Share in Total (India) Domestic Product Average over 1980-81 - 2014-15

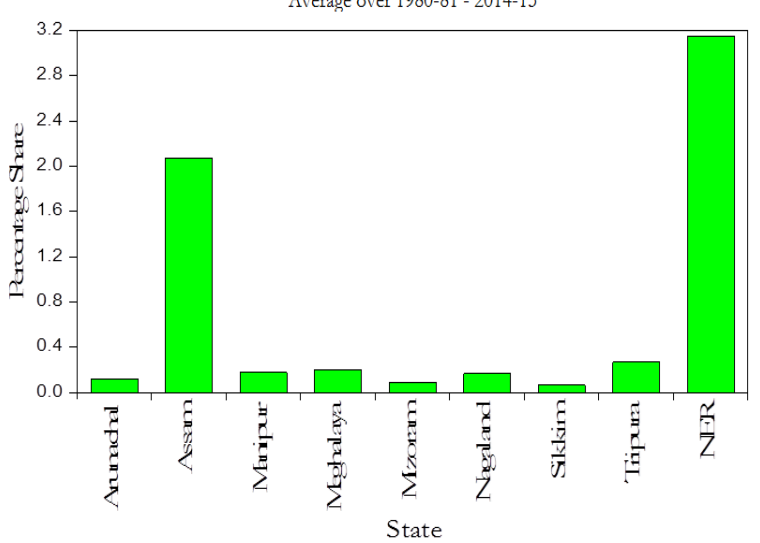

(c)
Percentage Share in Total (India) Population

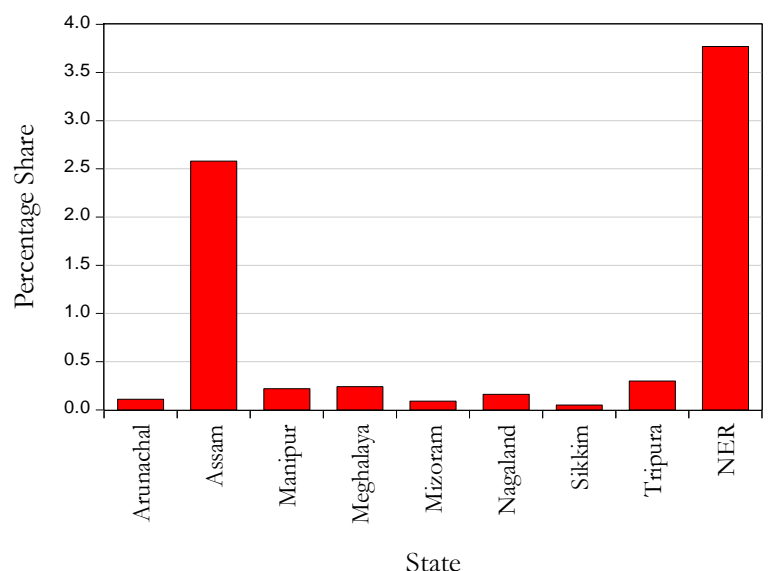

(b)

Sectoral Shares in Total State Income: 2013-14

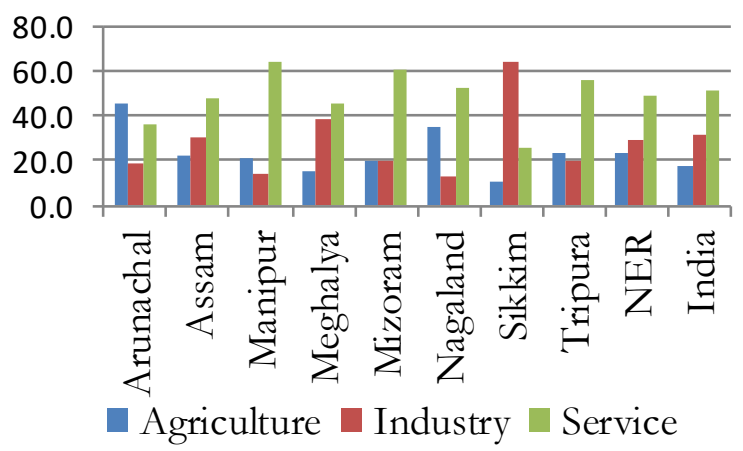

(d)

Figure 1: Macroeconomic characteristics of the Northeastern states Note: The graphs are generated by using data from the Central Statistics Office (CSO), India.

Percentage Share of NER in India's Net Domestic Product

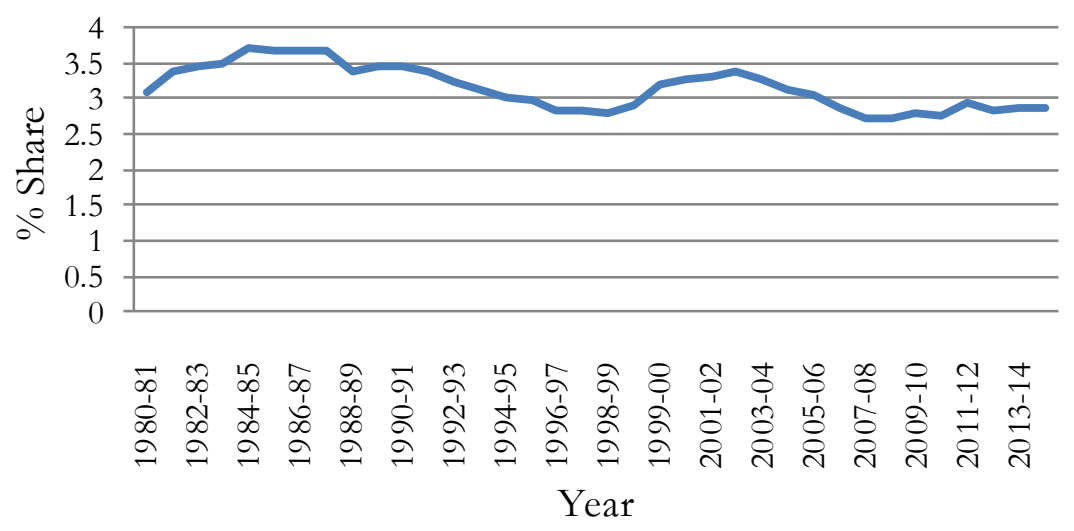

Figure 2: NER's contributions to Indian Economy - 1980-81 to 2013-14

Note: The graph is generated by using data from the Central Statistics Office (CSO), India. 
Finally, ICT and ICT-enabled service revolution of the 2000s had little growth enhancing effect on the economy of the region. The only effect, albeit negative, was a large-scale exodus of skilled and low-skilled workers from the region to the growth centres (such as Bengaluru, Hyderabad, Pune, Delhi) in the country. One can argue that the repatriated income of the migrants would boost demand that in turn would lead to growth in the home region. However, demand-driven growth with little investment in productive capacity would not be beneficial to the region in the long run. Besides, the increased demand would also largely benefit the producers who are located outside the region.

Due to a number of factors, the investment has not been taking place. There is a lack of entrepreneurship among the people of the region. Various government schemes to encourage entrepreneurship and to create entrepreneurs have had limited success. Further, there are a small number of entrepreneurs who are often constrained by the availability of credit. Socio-political unrests keep investment from outside the state at a distance. In fact, the increased insurgent activities contributed to the flight of capital from the region. The topography of the region and inadequate infrastructure also proved to be a hindrance for the growth of industries. The British coloniser built the infrastructure in such a way that they could extract and take out the resources from the region. Even after the independence, the same model continued. There were no initiatives to build industries even on the basis of the resources available in the region. Remoteness from the market and high transportation cost were typical economic reasoning for not developing industries. Because of the sensitive nature of the border region, it is not directly connected to the markets in the neighbouring countries. Everything had to be transported via a long winding route that often goes through Kolkata. Bezbaruah and Sarma (2009) have identified the lack of market access as a major hindrance for industrial growth in the region.

The development paradigm adopted by the central government for the northeast region in the early nineties includes various packages under which massive transfer of resources and concessions were made to the states in the region. These measures increased consumption but failed to build the production base, which is essential for sustainable growth. Following a high-level commission report to the Prime Minister in 1997, the "northeast development concern" was included in LEP. The emergence of LEP as a policy framework for development of the northeast is often referred to as a new paradigm of development for the northeast. ${ }^{5}$

\section{India's Look/Act East Policy}

India's LEP is intended to develop extensive economic and strategic relations primarily with the Southeast Asian countries. This policy was formulated and initiated by PV Narasimha Rao's government in the early 1990s. Since then there has been constant evolution of the policy under successive governments. The current National Democratic Alliance (NDA) government has rechristened it as the Act East Policy (AEP).

After independence India pursued insular and protectionist policies. ${ }^{6}$ The dislike and distrust of the western colonial power led India, like many other erstwhile colonies, to adopt economic policies that emphasized self-reliance through promotion of heavy industries in the public sector. Influenced by the socialistic pattern of economic growth in the Soviet Union, Prime Minister Nehru chose a mixed economy model with preponderance of the public sector and five-year economic planning. In the area of international polity and diplomacy, India was one of the pioneers of the

\footnotetext{
${ }^{5}$ See Baruah and Das (2008) for a discussion.

${ }^{6}$ It has become a common knowledge as numerous research articles and textbook discussions on India's macroeconomic policy mention this fact. For a ready reference on LEP related discussion, please see Strachan et al (2009).
} 
concept of non-alignment. The member countries of the Non-Aligned Movement (NAM) do not want to be officially aligned (friends) with or against any major power bloc (group of countries).

The Southeast Asian region was economically less developed until the 1960s when it started growing rapidly. ${ }^{7}$ Besides, India and the countries from this region were on opposite sides of the Cold War Divide. After the collapse of the Soviet Union and the end of cold war, there emerged a new world order and India sought realignment by directing its focus towards east. Due to its colonial links, India always looked up to the West and, over the centuries, built up economic ties primarily with the western countries. Thus, the launch of LEP signifies a strategic shift in India's view of the world in the post-cold war period. As India embarked on economic liberalisation and market-oriented reforms in 1991, it reoriented its foreign policy towards the countries to its east. A balance of payments crisis at the time paved the way for an International Monetary Fund (IMF) program that led to the adoption of these major reforms. ${ }^{8}$ Although, in the initial phase, the focus of LEP was on economic diplomacy in order to create and expand regional markets for trade, investments, and industrial development, it gradually put increasing emphasis on strategic and security cooperation and revival of historic cultural and ideological links in the subsequent phases of LEP. ${ }^{9}$ The growing concerns over the expansion of China's economic and strategic influence among the nations in this region facilitated India's strategic and military cooperation with these nations.

\footnotetext{
${ }^{7}$ For a comparison of growth experiences of the Southeast Asia with other regions of the continent, see Radel et et al (1997). However, there have been substantial differences in the rate of economic growth even among the countries in this region. Nevertheless, as Hill (2014) shows, these countries a re converging in several macroeconomic performance indicators in recent decades.

${ }^{8}$ However, as Panagariya argues, economic liberalisation in India can be traced back to the late 1970s.

${ }^{9}$ For a detailed analysis of the evolution and approach of LEP, see Haokip (2011).
}

Under LEP, India has established and promoted relationships in several areas with countries in East, Southeast, and South Asia. For example, over last two decades or so, India has signed free trade agreements (FTAs) with the Association of Southeast Asian Nations (ASEAN), Singapore, South Korea, Japan, Malaysia, Sri Lanka, Nepal, Bhutan and other Southeast, East and South Asian economies. It is negotiating agreements with Indonesia, Thailand, Australia, and New Zealand. ${ }^{10}$ Despite India's support for Myanmar's pro-democracy movement, India started economic and military cooperation with that country in the early 1990s as a strategic move to counter Chinese domination in the region. ${ }^{11}$ Indian public sector corporations secured lucrative contracts for industrial projects and the construction of major roads and highways, pipelines and upgrading of ports. In order to cater to its growing domestic needs of oil and natural gas and to reduce its dependence on the Middle East, India entered into competition with China by investing in oil and natural gas exploration in Myanmar. However, China was awarded the contracts for extracting more than 2.88-3.56 trillion cubits of natural gas in the A-1 Shwe field in the Rakhine State. Furthermore, China was asked to develop naval and surveillance installations along Burma's coast and the Coco Islands. Besides, China remains Burma's largest military supplier. These have been major setbacks for India. Yet, India has increased cooperation with the country in training of military personnel and in curbing separatist militants and heavy drug trafficking affecting much of Northeast India.

Strong commercial, military, and cultural relations have been established with the Philippines, Singapore, Vietnam, and Cambodia. In particular, the strategic importance of these countries, particularly of Singapore, has been heightened. In addition to the initiatives to improve economic ties, India has also been conducting joint naval exercises with Singapore

\footnotetext{
${ }^{10}$ A complete list of India's FTAs and their current status are included in Appendix Table A.1

${ }^{11}$ Bhaumik (2007) discusses India's double standards in its policy towards Myanmar.
} 
(SIMBEX) since 1993, with Vietnam in 2000 and has engaged in joint patrols with Indonesia in the Andaman Sea since 2002. Since more than $50 \%$ of India's trade passes through the Malacca Strait, the Indian navy has established a Far Eastern Naval Command off Port Blair on the Andaman and Nicobar Islands. India has also strengthened its ties with Japan, South Korea, and Taiwan. The emphasis of these relationships has been on the shared principles of democracy, human rights and strategic interests. After the market-oriented reforms and economic liberalisation of the 1990s, South Korea and Japan have become the major sources of foreign investment in India. Although India supports the "One China" policy and recognizes the authority of the People's Republic of China over the Republic of China (Taiwan), it has, however, stepped up its engagement with the island. India's growing need for cooperation on counter-terrorism, humanitarian relief, anti-piracy, maritime and energy security, confidence-building and balancing the influence of China has propelled its desire and action towards increasing engagement with East Asia. ${ }^{12}$

Engagement with the ASEAN member countries was the initial focus of LEP. India became a sectoral dialogue partner with ASEAN in 1992, was given an advisory status in 1995, a member of the Council for Security Cooperation in the Asia-Pacific, a member of the ASEAN Regional Forum in 1996, and a summit-level partner (on par with China, Japan and Korea) in 2002. In several instances, a desire by the countries in the region to balance China's growing influence in the area has led to India's membership to various forums. For example, Japan was instrumental in bringing India into ASEAN+6 to weaken the ASEAN+3 processes, where China plays a dominant role. Similarly, the United States and Japan have pressed for India's inclusion in the Asia-Pacific Economic Cooperation (APEC) as one of its members. Furthermore, India's entry into the East Asia

\footnotetext{
${ }^{12}$ For a discussion on India's strategic alignment with the countries in Asia-Pacific region and LEP, see Ladwig III (2009)
}

Summit was strongly supported by Singapore and Indonesia.

The strategic perspective of LEP is very important not only for India but also for the countries in South and Southeast Asia. It needs to be evaluated in the context of the rising dominance of China. As a part of LEP, India has engaged in Bay of Bengal Initiative for MultiSectoral Technical and Economic Cooperation (BIMSTEC), Asia Cooperation Dialogue (ACD), Mekong Ganga Cooperation (MGC) and Indian Ocean Rim Association (IORA) for extensive cooperation on economic development, environmental issues, security and strategic matters. These initiatives are intended to grow India's influence beyond South Asia. Note that its efforts in the South Asian Association for Regional Cooperation (SAARC) have often been thwarted by the obstructive presence of Pakistan and China.

There have been numerous infrastructure projects under LEP that are expected to tie India closer to East and Southeast Asia. India is participating in the United Nations Economic and Social Commission for Asia and the Pacific and the Pacific initiatives for an Asian Highway Network and the Trans-Asian Railway network. There have been discussions on reopening the World War II-era Stilwell Road that would link Assam with China's Yunnan province via Myanmar. The other infrastructure projects that are in various stages of completion include Moreh-Tamu-Kalewa Road, India-MyanmarThailand Trilateral Highway, Trans-Asian Highway, India-Myanmar rail linkages, Kaladan Multimodal project, Myanmar-IndiaBangladesh gas and/or oil pipeline, Tamanthi Hydroelectricity project and optical fibre network between Northeast India and Southeast Asia (Shrivastava 2013).

The Integration of NER in LEP was somewhat an afterthought and it adds a domestic dimension to LEP, known as Look East through Northeast. This also signifies the beginning of a second phase of LEP. To connect India with Southeast and East Asia, NER is considered as a bridge to the present gap. The region has the potential to develop into one of the India's economic power 
station. NER is enriched with oil, natural gas, coal and limestone. This region is also rich in various horticultural products, spices, rare herbs and medicinal plants. NER offers unlimited tourism opportunities, natural scenic beauty, unique performing arts and various local cuisine and handicrafts. ${ }^{13}$ The main aspects of LEP-NER are: (a) connectivity and physical infrastructure to facilitate trade; (b) trade and investment protocol; (c) shortfalls in operationalization of existing assets and facilities; (d) soft aspects of bilateral/multilateral relationships such as in tourism and enhanced people to people interaction through sports, culture, academic and medical research, etc.

The NDA government under the leadership of Prime Minister Narendra Modi has made India's relations with East and Southeast Asian neighbours a foreign policy priority at a time when the United States under President Barrack Obama engaged in a "pivot to Asia". The Indian Foreign Minister Sushma Swaraj proposed anew outlook calling it Act East Policy, following on from the Look East policy. The defining feature of this third phase of LEP is projected to be the speed of engagement and connectivity in broader sense. It is being defined as C3 (communication, culture and connectivity). It has been clarified that AEP does not supplement LEP rather recalibrate it. AEP focuses on certain key resources and initiatives like transboundary water sharing, cultural and trade exchanges and better infrastructure development for connectivity in the region.

\section{A Critical Assessment of the Opportunities and Challenges under LEP or/and AEP}

One expectation about the potential benefits to the region from LEP/AEP is based on the prospect of increased trade through India's eastern border. In order to assess this prospect, let us first take a look at some facts about India's trade.

\footnotetext{
${ }^{13}$ The potential for tourism has been discussed in many forums. See, for example, Shrivastava (2013) and Seshadri (2017).
}

Table 1 lists the top eleven of India's export partner countries and top eleven of its import partner countries. Among the top export destinations, Hong Kong, China, Singapore, Bangladesh, and Vietnam in the East, Southeast and South Asia region account for about $15 \%$ of total exports from India in 2015. Among the top import sources, China is the largest with about $16 \%$ of India's total imports. Indonesia and South Korea are also among the top eleven importers. These three countries together account for about $23 \%$ of total imports to India. Overall, India has trade deficit with the countries taken together in this region. According to some estimates, NER accounts for about $2 \%$ of total trade with Southeast Asian countries. Thus, if the trend continues, NER will not directly benefit.

We would now take a look at the major trade items and see if NER produces any of those items. Table 2 shows the top 10 export and top 10 import items. Although NER produces crude oil and petroleum products, they do not constitute a major part of the export items. Most of the mineral fuels exported from India are produced (refined) and exported from the refineries owned by Reliance Industries Limited (RIL) in Jamnagar in Gujarat. The combined refining capacity of all four refineries in Assam is about 7 million metric ton whereas two refineries in Jamnagar can refine a total of about 60 million metric ton of crude oil. ${ }^{14}$ The facts presented in the tables suggest that if the eastern border via the NER is opened, there is not much in terms of products produced in the region that can be exported to the countries in the East, Southeast and South Asian region.

\footnotetext{
${ }^{14}$ These figures are obtained from a report "India's crude oil refining capacity: a snapshot" published in Business Standard on February 20, 2016 (http://www.businessstandard.com/article/economy-policy/india-s-crude-oilrefining-capacity-a-snapshot-116022000047_1.html, accessed on Friday, September 1, 2017)
} 


\begin{tabular}{|c|c|c|c|c|c|c|c|}
\hline \multicolumn{4}{|c|}{ Panel A: Major export destinations } & \multicolumn{4}{|c|}{ Panel B: Major import sources } \\
\hline Rank & Country & $\begin{array}{l}\text { Value } \\
\text { (US\$ } \\
\text { billion) }\end{array}$ & $\begin{array}{l}\text { Share } \\
\text { of } \\
\text { overall } \\
\text { exports }\end{array}$ & Rank & Country & $\begin{array}{l}\text { Value } \\
\text { (US\$ } \\
\text { billion) }\end{array}$ & $\begin{array}{l}\text { Share } \\
\text { of } \\
\text { overall } \\
\text { imports }\end{array}$ \\
\hline 1 & United States & 40.4 & $15.3 \%$ & 1 & China & 61.5 & $15.8 \%$ \\
\hline 2 & $\begin{array}{l}\text { United Arab } \\
\text { Emirates }\end{array}$ & 30.3 & $11.5 \%$ & 2 & Saudi Arabia & 21.4 & $5.5 \%$ \\
\hline 3 & Hong Kong & 12.2 & $4.6 \%$ & 3 & Switzerland & 21.1 & $5.4 \%$ \\
\hline 4 & China & 9.5 & $3.6 \%$ & 4 & United States & 20.5 & $5.2 \%$ \\
\hline 5 & $\begin{array}{l}\text { United } \\
\text { Kingdom }\end{array}$ & 8.9 & $3.4 \%$ & 5 & $\begin{array}{l}\text { United Arab } \\
\text { Emirates }\end{array}$ & 20.3 & $5.2 \%$ \\
\hline 6 & Singapore & 7.8 & $3 \%$ & 6 & Indonesia & 13.9 & $3.5 \%$ \\
\hline 7 & Germany & 7 & $2.7 \%$ & 7 & South Korea & 13.1 & $3.4 \%$ \\
\hline 8 & Saudi Arabia & 7 & $2.7 \%$ & 8 & Germany & 11.8 & $3 \%$ \\
\hline 9 & Sri Lanka & 5.5 & $2.1 \%$ & 9 & Iraq & 11.3 & $2.9 \%$ \\
\hline 10 & Bangladesh & 5.5 & $2.1 \%$ & 10 & Nigeria & 10.2 & $2.6 \%$ \\
\hline 11 & Vietnam & 5.3 & $2 \%$ & 11 & Qatar & 9.7 & $2.5 \%$ \\
\hline
\end{tabular}

Of course, if the NER is used as a corridor for transporting goods produced in other parts of the country, there will be some indirect benefits. There will be demand for some auxiliary services such as hotels, fuel pumps, and restaurants that will have some contributions to growth of the local economy. Even this could be problematic as the connectivity of the region with the country's mainland via the chicken's neck involves longer distance and higher transportation costs. As Bhaumik (2014) argues, the region's rail and road connections with Kolkata and other parts of India via Bangladesh would be shorter and more cost efficient. However, there are issues - both bilateral and internal to Bangladesh that would hinder establishment of connectivity between NER and India's mainland via Bangladesh. The markets in NER are likely to be flooded with cheap consumer goods produced primarily in China and to a lesser extent in Bangladesh. It will create competitive pressure for the domestic industries. As we have discussed above, industrial growth has already been lagging behind in NER despite various government incentives. This competitive pressure may create another hurdle. The northeast region does not have good access to the Indian market. Because of its geographical distance from the country's mainland, despite major incentives few businesses are interested in building production hub in the region. Producing in the region and selling in the western or southern parts of India become excessively expensive. Even within the region, the road and railroad connectivity has been poor. It has been a major constraint in the development of the market. ${ }^{15}$

Since better connectivity with the neighbouring countries will potentially ameliorate the problem of access to the market, will better connectivity alone attract investment? As far as the local entrepreneurship and investment go, there is a dearth of both.

\footnotetext{
${ }^{15}$ See Barua and Das (2008) for a discussion.
} 


\begin{tabular}{|c|c|c|c|c|c|}
\hline Rank & Export items & $\%$ share & Rank & Import items & $\%$ share \\
\hline 1 & $\begin{array}{l}\text { Mineral Fuels, Mineral } \\
\text { Oils And Products Of } \\
\text { Their Distillation; } \\
\text { Bituminous Substances; } \\
\text { Mineral Waxes. }\end{array}$ & 18.54 & 1 & $\begin{array}{l}\text { Mineral Fuels, Mineral } \\
\text { Oils And Products Of } \\
\text { Their Distillation; } \\
\text { Bituminous Substances; } \\
\text { Mineral Waxes. }\end{array}$ & 34.87 \\
\hline 2 & $\begin{array}{l}\text { Natural Or Cultured } \\
\text { Pearls, Precious Or } \\
\text { Semiprecious Stones }\end{array}$ & 13.39 & 2 & $\begin{array}{l}\text { Natural Or Cultured } \\
\text { Pearls, Precious Or } \\
\text { Semiprecious Stones }\end{array}$ & 13.93 \\
\hline 3 & $\begin{array}{l}\text { Vehicles Other Than } \\
\text { Railway Or Tramway } \\
\text { Rolling Stock, And Parts } \\
\text { And Accessories }\end{array}$ & 4.67 & 3 & $\begin{array}{l}\text { Electrical Machinery And } \\
\text { Equipment And Parts }\end{array}$ & 7.4 \\
\hline 4 & $\begin{array}{l}\text { Nuclear Reactors, Boilers, } \\
\text { Machinery And } \\
\text { Mechanical Appliances }\end{array}$ & 4.45 & 4 & $\begin{array}{l}\text { Nuclear Reactors, Boilers, } \\
\text { Machinery And } \\
\text { Mechanical Appliances }\end{array}$ & 7.09 \\
\hline 5 & Organic Chemicals & 3.85 & 5 & Organic Chemicals & 3.96 \\
\hline 6 & Pharmaceutical Products & 3.73 & 6 & Iron And Steel & 2.76 \\
\hline 7 & Cereals & 3.08 & 7 & Plastic & 2.61 \\
\hline 8 & $\begin{array}{l}\text { Apparel And Clothing } \\
\text { Accessories, Not Knitted } \\
\text { Or Crocheted }\end{array}$ & 2.96 & 8 & $\begin{array}{l}\text { Animal Or Vegetable Fats } \\
\text { And Oils And Their } \\
\text { Cleavage Products; Pre. } \\
\text { Edible Fats; Animal Or } \\
\text { Vegetable Waxes }\end{array}$ & 2.38 \\
\hline 9 & $\begin{array}{l}\text { Electrical Machinery And } \\
\text { Equipment And Parts }\end{array}$ & 2.8 & 9 & Miscellaneous Goods. & 1.67 \\
\hline 10 & Iron And Steel & 2.8 & 10 & Ores, Slag And Ash & 1.64 \\
\hline & $\begin{array}{l}\text { Total exports in crores of } \\
\text { INR }\end{array}$ & 182,220 & & $\begin{array}{l}\text { Total imports (in crores of } \\
\text { INR) }\end{array}$ & $268,555.7$ \\
\hline
\end{tabular}

This has been identified as a fundamental railroads from meter gauge to broad gauge and hurdle for industrial development in the NER their extension, and power generation projects (see Bezbaruah and Sarma 2009). Therefore, it are under way. However, it has been slowed by is unlikely that there will be a substantial a whole host of factors including oppositions domestic investment from the region from various interest groups and civil society overnight. What about investment from other organizations. The other important factor that parts of the country or from the rest of the is a deterrent for capital from outside is the world? There are certain preconditions that socio-political instability. Most states in the need to be satisfied before investment from northeast region have withstood the worst of outside the state or from abroad flows in. The insurgency for a long period. In states like infrastructural bottlenecks are one major issue. Manipur and Nagaland, there is still active Works on highway projects, conversion of insurgency that would not help with foreign 
capital. ${ }^{16}$ Finally, rampant corruption, bureaucratic red-taps, and overall inferior quality of institutions are major deterrents for investment from outside, particularly from abroad. ${ }^{17}$

The other challenge is that NER can be connected to Southeast Asian countries only through Myanmar. Until recently, the country was ruled by a Military Junta. Although India was opposed to the military rule, it started diplomacy and strategic partnership in 1993. In order to access the markets in other East and Southeast Asia, it is important that Myanmar also develop their road and railway infrastructure. For a long period, heavy sanctions were imposed on the country by the international community. Hopefully, the return to democracy and improvement in political situation will be able to attract investments and aids so that Myanmar can invest in crucial infrastructure.

While developing manufacturing base for producing goods for East and Southeast Asian markets could be a task of tall order and faces formidable challenges, there are at least three service areas where NER may find the markets in that region relatively easily. They are: education, healthcare and tourism. There have been recent initiatives to establish institutions of higher education in the northeastern states. The mandates of these institutions are narrowly focused in the region although the central government institutions have been able to attract students and teachers from outside the region. In the Southeast Asian region, Bangkok and Singapore have been internationally recognised as centres of higher learning. Given the demographic composition of the region, there is a need for additional centres for higher education institutes of excellence. NER can step in to fill this void. The existing institutes can

16 Baruah and Das (2008) highlight the issue of uncertainty and insecurity created by insurgency in the minds of economic agents who take decisions regarding production and investment.

${ }^{17}$ Baruah and Das (2008) also discuss how some of the government policies to contain socioeconomic problems have led to rampant corruption in the NER states. Also, see Rahman (2013). reorient their student and faculty recruitment policies. There could be more investment in establishing new institutions of higher learning in both private as well as public sector. This will also attract investment in other informationintensive services that require highly skilled workers.

There are several medical colleges and hospitals in NER. With the establishment of the All India Institute of Medical Sciences (AIIMS) in Assam, the region will potentially be a hub of medical education and healthcare services. ${ }^{18}$ In the Southeast Asian region, Bangkok and Singapore are considered centres of healthcare services. But geographic proximity of NER particularly to Bangladesh and Myanmar provides an opportunity for developing economically profitable healthcare industry. Of course, along with road and railway infrastructure, development of air transportation and travel would be conducive to this endeavour.

Finally, tourism can be a service industry that could potentially generate economic benefits to the states of the region. Nature tourism that includes visits to wildlife and biodiversity areas, adventure tourism, religious and cultural tourism has great potential in the entire region. However, it is very important that development of tourism industry should not destroy and disturb the nature and ecological balance in the region. Note that because of rains and floods during the summer/monsoon months in the region, tourism will be seasonal in nature and that should be taken into account while developing it as an industry. Besides, there is a need for mass literacy for the people who will be directly or indirectly involved in tourism. Because of the ethno-cultural ties with the people in surrounding countries (Thailand,

\footnotetext{
${ }^{18}$ The construction of AlIMS in Kamrup (Rural) District of Assam has already begun with the laying of the foundation stone by the Prime Minister of India on June 23, 2017. (Hindustan Times, June 24, 2017, http://www.hindustantimes.com/india-news/modi-laysfoundation-stone-for-aiims-unit-in-assam-to-becompleted-in-4-years/story-

SPVnKiyO8BIYLSLGOJspMM.html, accessed on Friday, September 1, 2017)
} 
Myanmar, Tibet, Bangladesh, Nepal), there is a scope for cultural tourism as well. Again, being sensitive to the traditions and cultures of various ethnic groups while opening up the region to tourists from other lands is very important. In the era of sociological liberalism and complex interdependence, cultural diplomacy is one of the tools for developing people-to-people connectivity. India is developing partnership with CLMV countries (Cambodia, Laos, Myanmar and Vietnam) at bilateral and multilateral level. A Buddhist tourism circuit can be developed in Arunachal Pradesh and Sikkim because large population of Buddhists live in CLMV countries, China, Thailand, Japan and Singapore.

\section{Conclusion}

Regional integration of NER with the countries in East, Southeast and South Asia may potentially generate economic dividends to the region. ${ }^{19}$ However, there are formidable challenges in realising the potentials. The proposed infrastructure projects, if completed with no further delay, will go a long way in improving connectivity with the neighbouring countries. However, improving connectivity within the region and with the rest of the country is also very important. Further, it would require a comprehensive long-term plan with well-defined projects for developing industries and services including education, health and tourism. Building infrastructure, ensuring sociopolitical stability and ecological balance, and improving the quality of institutions would be a major part of this plan.

\section{References}

Barua, A., Das, S. K. 2008. Perspectives on Growth and Development in the Northeast: The Look East Policy and Beyond. Margin: The Journal of Applied Economic Research 2: 4, 327350.

Baruah, S. 2004. Between South and Southeast Asia: Northeast India and the Look East Policy. CENISEAS Papers 4.

\footnotetext{
${ }^{19}$ Baruah (2004) dwells upon regional integration across national borders under LEP as a broad framework for overall development of NER.
}

Bezbaruah, M. P., Sarma, A. 2009. Industry in the Development Perspective of North East India. Dialogue, Volume 10, No. 3 (March).

Bhaumik, S. 2007. Explaining India's silence over Burma. BBC News, 26 September (http://news.bbc.co.uk/2/hi/south_asia/70139 75.stm, accessed on Friday, September 1, 2017) Bhaumik, S. 2014. 'Look East through Northeast': Challenges and Prospects for India. Observer Research Foundation Occasional Paper \# 51 (June).

Das, G. D. 2012. Security and Development in India's Northeast. New Delhi: Oxford University Press.

Guha, P., Mohapatra, R. 2016. Intensity and Pattern of Border Trade in India's Northeast. Foreign Trade Review 51(3): 248-265

Haokip, T. 2011. India's Look East Policy: Its Evolution and Approach. South Asian Survey, Vol. 18, No. 2, 239-257.

Hill, H. Is There a Southeast Asian Development Model? University of Freiburg Department of International Economic Policy Discussion Paper Series No. 26.

Ladwig III, W. C. 2009. "Delhi's Pacific Ambition: Naval Power, 'Look East,' and India's Emerging Role in the Asia Pacific," Asian Security, Vol. 5, No. 2, pp. 98-101.

Moral, D. 1997. "North-East India as a Linguistic Area" (PDF), Mon-Khmer Studies, 27: 43-53

Panagariya, A. 2001. India's Economic Reforms What Has Been Accomplished? What Remains to Be Done? EDRC POLICY BRIEF NO. 2. Asian Development Bank.

Radelet, S., Sachs, J., Lee, JW. 1997. “Economic Growth in Asia." Background paper for the Asian Development Bank's Emerging Asia study. HIID Development Discussion Paper No. 609, November 1997

Rahman, S. Y. 2013. The North-East India's Look East Policy. InPEC Magazine, May.

Seshadri, S. 2017. India's North East Opens: The Gateway to Prosperity, The Masterbuilder, June 19. https://www.masterbuilder.co.in/indias- 
north-east-opensthe-gateway-prosperity/, accessed on Friday, September 1, 2017)

Shrivastava, S. 2013. North East India and India's Look East Policy. The World Reporter, June 18

Strachan, A.L., Kang, H. K., Sinha, T. 2009. India's Look East Policy: A Critical Assessment (Interview with Amb. Rajiv Sikri). Institute of Peace and Conflict Studies (IPCC) Special Report, October.

\section{Acknowledgements}

This paper was written when the corresponding author (Nath) was a Visiting Professor at the Department of Humanities and Social Sciences, Indian Institute of Technology, Guwahati (IITG), India. He is grateful to the department and IITG for their hospitality. The authors would like to thank an anonymous reviewer for his or her useful comments. Usual disclaimer applies.

\section{Appendix}

\section{Table A.1: India's Free Trade Agreements with Different Countries and Groups of Countries and Their Current Status}

\begin{tabular}{|c|c|c|}
\hline $\begin{array}{l}\text { Sl. } \\
\text { No. }\end{array}$ & Free Trade Agreement (FTA) & Status \\
\hline 1 & India-Gulf Cooperation Council Free Trade Area & (FA) signed \\
\hline 2 & $\begin{array}{l}\text { Bay of Bengal Initiative for Multi-Sectoral Technical } \\
\text { and Economic Cooperation (BIMSTEC) Free Trade } \\
\text { Area }\end{array}$ & Negotiations launched \\
\hline 3 & India - Eurasian Economic Union & Negotiations launched \\
\hline 4 & India-Australia Free Trade Agreement & Negotiations launched \\
\hline 5 & India-Canada Economic Partnership Agreement & Negotiations launched \\
\hline 6 & India-Egypt Preferential Trade Agreement & Negotiations launched \\
\hline 7 & $\begin{array}{l}\text { India-European Free Trade Association Free Trade } \\
\text { Agreement }\end{array}$ & Negotiations launched \\
\hline 8 & India-European Union Free Trade Agreement & Negotiations launched \\
\hline 9 & $\begin{array}{l}\text { India-Indonesia Comprehensive Economic } \\
\text { Cooperation Arrangement }\end{array}$ & Negotiations launched \\
\hline 10 & India-Israel Free Trade Agreement & Negotiations launched \\
\hline 11 & $\begin{array}{l}\text { India-Mauritius Comprehensive Economic } \\
\text { Cooperation and Partnership Agreement }\end{array}$ & Negotiations launched \\
\hline 12 & $\begin{array}{l}\text { India-Southern African Customs Union Preferential } \\
\text { Trade Agreement }\end{array}$ & Negotiations launched \\
\hline 13 & India-Thailand Free Trade Area & Negotiations launched \\
\hline 14 & New Zealand-India Free Trade Agreement & Negotiations launched \\
\hline 15 & Regional Comprehensive Economic Partnership & Negotiations launched \\
\hline 16 & $\begin{array}{l}\text { ASEAN-India Comprehensive Economic Cooperation } \\
\text { Agreement }\end{array}$ & Signed and In Effect \\
\hline 17 & Asia-Pacific Trade Agreement & Signed and In Effect \\
\hline 18 & India-Afghanistan Preferential Trading Agreement & Signed and In Effect \\
\hline 19 & India-Bhutan Trade Agreement & Signed and In Effect \\
\hline 20 & India-Chile Preferential Trading Agreement & Signed and In Effect \\
\hline 21 & India-MERCOSUR Preferential Trade Agreement & Signed and In Effect \\
\hline 22 & $\begin{array}{l}\text { India-Singapore Comprehensive Economic } \\
\text { Cooperation Agreement }\end{array}$ & Signed and In Effect \\
\hline
\end{tabular}


23 India-Sri Lanka Free Trade Agreement

24 India-[Republic of] Korea Comprehensive Economic Partnership Agreement

25 Indo-Nepal Treaty of Trade

26 Japan-India Comprehensive Economic Partnership Agreement

27 Malaysia-India Comprehensive Economic Cooperation Agreement

28 South Asian Free Trade Area
Signed and In Effect

Signed and In Effect

Signed and In Effect

Signed and In Effect

Signed and In Effect

Signed and In Effect

Source: Asia Regional Integration Center, Asian Development Bank,

Website: https://aric.adb.org/fta-country, accessed on June 22, 2017 